\title{
The biochemical and hematological parameters of patients with acoustic trauma caused by gunshot noise
}

\author{
Silah sesi nedeniyle akustik travma geçiren hastalarm biyokimyasal ve \\ hematolojik parametreleri \\ Murat Salihoğlu, ${ }^{1}$ Onuralp Kurt, ${ }^{2}$ Aytuğ Altundağ, ${ }^{3}$ Melih Çayönü ${ }^{4}$ \\ ${ }^{1}$ Department of Otolaryngology, Gata Haydarpaşa Training Hospital, İstanbul, Turkey \\ ${ }^{2}$ Department of Otolaryngology, Erzincan Military Hospital, Erzincan, Turkey \\ ${ }^{3}$ Department of Otolaryngology, İstanbul Surgery Hospital, İstanbul, Turkey \\ ${ }^{4}$ Department of Otolaryngology, Amasya University S.S. Training and Research Hospital, Amasya, Turkey
}

\begin{abstract}
Objectives: In this study, we aimed to evaluate the biochemical and hematologic parameters of patients with acoustic traumainduced hearing loss caused by gunshot noise.

Patients and Methods: Fifty one male participants $(23.1 \pm 3.4$ years; range 21 to 36 years) were included in the study. The acoustic trauma group was constituted of 25 patients admitted with hearing loss after the firearm training. Whereas the healthy controls were selected randomly from the participants $(n=26)$ without any complaint of hearing loss or tinnitus after the same firearm training. The biochemical and hematological parameters were compared between the study and control groups.
\end{abstract}

Results: Serum folate and vitamin B12 levels were decreased in patients with acoustic trauma compared to healthy controls ( $\mathrm{p}<0.001$ and $\mathrm{p}=0.04$, respectively). Homocysteine levels were significantly increased in patients with acoustic trauma than the control group $(\mathrm{p}<0.001)$. Activated partial thromboplastin time was significantly shorter in patients with acoustic trauma than healthy controls $(\mathrm{p}<0.001)$.

Conclusion: The changes in folate, vitamin B12, and homocysteine levels may contribute, in part at least, to the pathophysiological mechanism of acoustic trauma. Therefore, these parameters should be investigated in patients with acoustic trauma-induced hearing loss.

Key Words: Acoustic trauma; folate; homocysteine; sensorineural hearing loss; vitamin B12.

Acute acoustic trauma (AAT) causes sudden sensorineural hearing loss (SNHL) due to exposure to acoustic overstimulation. ${ }^{[1]}$ There is a critical intensity

\begin{abstract}
Amaç: Bu çalışmada silah sesi nedeniyle akustik travmaya bağ $\mathrm{l}_{1}$ işitme kaybı oluşan hastaların biyokimyasal ve hematolojik parametreleri değerlendirildi.

Hastalar ve Yöntemler: Elli bir erkek katılımcı (ort. yaş 23.1 \pm 3.4 yıl; dağılım, 21-36 yıl) bu çalışmaya dahil edildi. Akustik travma grubu ateşli silah eğitimi sonrası işitme kaybı gelişen 25 hastadan oluştu. Buna karşılık aynı ateşli silah eğitimi sonrası işitme kaybı veya tinnitus yakınması olmayan katılımcılar arasından rastgele sağlıklı kontroller seçildi $(n=26)$. Çalışma ve kontrol grupları, biyokimyasal ve hematolojik parametreler açısından karşılaştırıldı.
\end{abstract}

Bulgular: Sağlıklı kontrollere kıyasla serum folat ve B12 vitamin düzeyleri akustik travma hastalarında azaldı (sırasıyla, $\mathrm{p}<0.001$ ve $\mathrm{p}=0.04$ ). Homosistein düzeyleri, kontrol grubuna kıyasla, akustik travma hastalarında anlamlı düzeyde arttı $(\mathrm{p}<0.001)$. Aktive parsiyel tromboplastin zamanı akustik travma hastalarında sağlıklı kontrollerden anlamlı derecede daha kisaydı $(\mathrm{p}<0.001)$.

Sonuç: Serum folat, vitamin B12 ve homosistein düzeylerindeki değişimler akustik travma patofizyolojik mekanizmasına, en azından kısmen, katkıda bulunabilir. Bu nedenle, bu parametreler akustik travma kaynaklı işitme kaybı olan hastalarda araştırılmalıdır.

Anahtar Sözcükler: Akustik travma; folat; homosistein; sensörinöral işitme kaybı; B12 vitamini.

level for noise exposure. Permanent hearing loss may occur when the noise exposure exceeds this critical intensity level even after a brief period. ${ }^{[2]}$ Several 
factors such as presence of impulse noise, exposure time, peak sound pressure, age and concomitant use of ototoxic drugs are important in the development of permanent hearing loss. ${ }^{[3,4]}$ Firearms cause impulse noise when fired. Impulse noise exposure levels should not exceed 140-decibel (dB) sound pressure levels (SPL). However, a rifle shot can produce an impulse noise up to $157 \mathrm{~dB}$ SPL. ${ }^{[5,6]}$ Soldiers in the military service are exposed to impulse noise during firearms training. The simplest method for prevention of acoustic overstimulation is use of hearing protection. However, laws in many countries do not regulate conditions and obligations of hearing protection use. ${ }^{[4]}$

Acoustic trauma causes hearing loss by two main mechanisms including mechanical and metabolic pathways. Damage due to acoustic overstimulation in the organ of Corti causes hearing loss by a mechanical pathway while pro-inflammatory cytokines and hypoxia cause hearing loss through a metabolic pathway. ${ }^{[7]}$ The prevalence of noise induced hearing loss among individuals using firearms is up to $40-60 \% .{ }^{[6]}$ Although the tissues in the cochlea are mechanically exposed to the same traumatic injury in case of acoustic trauma, the cochlea damage shows significantly individual differences. There is not enough literature about the cause of individual differences in acoustic trauma cases in terms of hearing loss.

In this study, we aimed to investigate the biochemical and hematological parameters of patients with acoustic trauma caused by gunshot noise by comparing them with age and sex matched healthy controls exposed to the same acoustic overstimulation.

\section{PATIENTS AND METHODS}

This study was conducted at the otorhinolaryngology clinic of GATA Haydarpaşa Training and Research Hospital. Allinvestigations were performed in accordance with the declaration of Helsinki on biomedical studies involving human subjects, and informed consent was obtained from all participating subjects. Fifty-one male participants (mean age $23.1 \pm 3.4$ years; range 21 to 36 years) admitted to the otolaryngology service between January 2011 and June 2013 were included in the study. The acoustic trauma group was constituted of twenty five patients admitted with hearing loss after the firearm training. Whereas the healthy controls were selected randomly from the participants without any complaint of hearing loss or tinnitus after the same firearm training. All the firearms trainings were performed with G3 (A3 automatic infantry rifle/1983, Heckler \& Koch GmbH, Germany) rifles. Participants with a history of SNHL, chronic otitis media and smoking were not included in the study.
After taking a history and performing an otolaryngological examination, pure tone audiometry was measured at $0.5,1,2,4,6,8,10,12.5,14$ and $16 \mathrm{kHz}$ to detect the hearing threshold at each given frequency, using an AC40 clinical audiometer (Interacoustics AS, Assens, Denmark) in a sound-isolated room standardized according to the manufacturer's instructions. Air-conduction thresholds between 0.25 and $8 \mathrm{kHz}$ were measured using TDH-39 earphones and an MX41/AR cover (Interacoustics, Assens, Denmark). Bone-conduction thresholds between 0.5 and $4 \mathrm{kHz}$ were measured using an Oticon 60273 vibrator (Oticon, Smørum, Denmark). Pure tone average (PTA) was determined based on the air-conduction average threshold levels in each ear at $0.5,1,2$, and $4 \mathrm{kHz}$.

Tympanometric measurements were performed, after swallowing, on both ears of the 25 patients in the study group and the 26 participants in the control group, for a total of 102 ears, using an Impedance Audiometer AZ 26 (Interacoustics, Assens, Denmark).

Bone conduction audiometry and tympanometry were used to rule out the presence of middle ear diseases that would have precluded obtaining valid measures.

Sudden hearing loss was defined as a $>30 \mathrm{~dB}$ hearing level (HL) shift over three consecutive frequencies occurring within three days. However, there is no accepted threshold shift for AAT in the literature. In our study, the average hearing threshold of $\leq 20 \mathrm{~dB} \mathrm{HL}$ at high frequencies $(4,6,8,10,12.5,14$ and $16 \mathrm{kHz})$ was accepted as normal, whereas $>20 \mathrm{~dB}$ HL was abnormal (AAT).

Complete blood count, serum electrolytes $(\mathrm{Ca}, \mathrm{Na}$, $\mathrm{K}, \mathrm{Mg}$, phosphorus), routine biochemical tests, levels of homocysteine, vitamin B12, thyroid hormone, and urinary methylmalonic acid levels were measured from the received blood and urine samples of the participants upon admission to the clinic. Also, A1298C and C677T polymorphism of methylenetetrahydrofolate receptor analysis were performed.

\section{Statistical analysis}

Data analysis was performed by SPSS version 21.0 (IBM, SPSS Armonk, NY, USA). Non-parametric tests were used because the groups studied were smaller than 30. Data were expressed as means and standard deviations or as a median and a range, when appropriate. Mann-Whitney $U$ tests were used to compare the continuous variables between the study groups. The level of significance was set at 0.05 .

\section{RESULTS}

Two age-matched groups were constituted to compare the biochemical and hematologic parameters of patients 


\begin{tabular}{|c|c|c|c|}
\hline \multicolumn{4}{|c|}{$\begin{array}{c}\text { Table } 1 \\
\text { Descriptive statistics of the groups in terms of hematologic parameters }\end{array}$} \\
\hline \multirow[t]{2}{*}{ Parameters (normal values) } & Healthy controls $(\mathrm{n}=26)$ & Patients with acoustic trauma $(n=25)$ & $p$ \\
\hline & Mean \pm SD & Mean \pm SD & \\
\hline Hemoglobin (11.5-16 g/dl) & $15.1 \pm 1.18$ & $15.3 \pm 1.1$ & 0.26 \\
\hline Hematocrit (34-45\%) & $43.1 \pm 3.85$ & $44.9 \pm 3.2$ & 0.08 \\
\hline Mean corpuscular volume (80-96 fL) & $84.7 \pm 4.01$ & $87.1 \pm 3.9$ & 0.02 \\
\hline Platelet $(150000-40000(\mathrm{mc} / \mathrm{L})$ & $267.2 \pm 60.5$ & $267.3 \pm 52.9$ & 0.9 \\
\hline Mean platelet volume (5-15 fL) & $6.7 \pm 0.8$ & $7.1 \pm 1$ & 0.82 \\
\hline Activated partial thromboplastin time (23-35 s) & $25.2 \pm 3.3$ & $22.5 \pm 1.9$ & $<0.001$ \\
\hline Prothrombin time (11-13 s) & $12.1 \pm 0.8$ & $12.1 \pm 0.6$ & 0.7 \\
\hline
\end{tabular}

with acoustic trauma caused by gunshot noise with healthy controls. The descriptive statistics of the groups are shown in Table 1 and 2.

There were no significant changes between the two groups in terms of hemoglobin, hematocrit, platelet and mean platelet volume levels whereas, mean corpuscular volume was significantly higher in the acoustic trauma group than healthy controls $(\mathrm{p}=0.02)$.

While prothrombin time showed no significant change between the groups, activated partial thromboplastin time was significantly shorter in patients with acoustic trauma than healthy controls $(\mathrm{p}<0.001)$.
There was no significant difference between the groups in terms of serum $\mathrm{Na}, \mathrm{Ca}$ and $\mathrm{K}$ levels, whereas $\mathrm{Mg}$ levels were significantly lower in the acoustic trauma group than in controls $(\mathrm{p}=0.02)$. However, despite the significant difference between the groups in terms of $\mathrm{Mg}$ levels, $\mathrm{Mg}$ levels were within normal ranges in both groups.

There was no difference between the study groups in terms of aspartate aminotransferase (AST), alanine aminotransferase (ALT), urea, albumin and thyroid hormone levels. However, we found a significant increase in creatinine levels in patients with acoustic

Table 2

Descriptive statistics of the groups in terms of biochemical parameters

\begin{tabular}{|c|c|c|c|}
\hline \multirow[t]{2}{*}{ Parameters } & Healthy controls $(\mathrm{n}=26)$ & Patients with acoustic trauma $(n=25)$ & \multirow[t]{2}{*}{$p$} \\
\hline & Mean \pm SD & Mean \pm SD & \\
\hline Aspartate aminotransferase (5-40 U/L) & $21.3 \pm 4.4$ & $19.9 \pm 5.3$ & 0.12 \\
\hline Alanine aminotransferase $(10-60 \mathrm{U} / \mathrm{L})$ & $19 \pm 9.8$ & $23.3 \pm 12.1$ & 0.07 \\
\hline Calcium (8.8-10.6 mg/dl) & $9.2 \pm 0.3$ & $9.1 \pm 0.2$ & 0.13 \\
\hline Sodium (136-146 mmol/L) & $138.9 \pm 1.3$ & $139 \pm 1.7$ & 0.08 \\
\hline Potassium (3.5-5.1 mmol/L) & $4.4 \pm 0.3$ & $6.5 \pm 1.3$ & 0.5 \\
\hline Magnesium (1.8-2.6 mg/dl) & $1.9 \pm 0.3$ & $2.4 \pm 0.7$ & 0.02 \\
\hline Urea $(7.9-21 \mathrm{mg} / \mathrm{dl})$ & $11.7 \pm 0.7$ & $12.7 \pm 0.5$ & 0.3 \\
\hline Creatinine $(0.84-1.25 \mathrm{mg} / \mathrm{dl})$ & $0.96 \pm 0.07$ & $1.01 \pm 0.04$ & 0.02 \\
\hline Albumin $(3.5-5.2 \mathrm{~g} / \mathrm{dl})$ & $4.3 \pm 0.3$ & $4.3 \pm 0.2$ & 0.9 \\
\hline Homocysteine $(5-15 \mathrm{mmol} / \mathrm{L})$ & $12.9 \pm 6$ & $22.1 \pm 6.7$ & $<0.001$ \\
\hline Free triiodothyronine $(2.5-3.9 \mathrm{pg} / \mathrm{ml})$ & $3.23 \pm 0.52$ & $3.21 \pm 0.47$ & 0.95 \\
\hline Free thyroxine $(0.6-1.4 \mathrm{ng} / \mathrm{dl})$ & $1.13 \pm 0.22$ & $1.1 \pm 0.09$ & 0.89 \\
\hline Folate $(3-17 \mathrm{ng} / \mathrm{ml})$ & $4.45 \pm 1.52$ & $3.08 \pm 1.66$ & $<0.001$ \\
\hline Vitamine B12 (250-1100 pg/ml) & $338.75 \pm 104.43$ & $282.27 \pm 105.89$ & 0.04 \\
\hline Urinary methylmalonic acid $(0.6-3.6 \mathrm{mmol} / \mathrm{mol} \mathrm{crt})$ & $2.44 \pm 1.37$ & $3.98 \pm 5.09$ & 0.80 \\
\hline
\end{tabular}


trauma when compared with controls $(p=0.02)$. Despite this significant difference creatinine levels were within normal ranges in both groups.

In addition, we found a significant decrease in serum folate and vitamin B12 levels in acoustic trauma patients $(\mathrm{p}<0.001, \mathrm{p}=0.04$, respectively). In contrast to folate and vitamin B12 levels, a significant increase was found in homocysteine levels in acoustic trauma patients $(\mathrm{p}<0.001)$.

Although, no difference was detected between the groups in terms of urinary methylmalonic acid, the mean value of urinary methymalonic acid in the acoustic trauma patients was higher than the normal values.

Finally, no difference was detected between acoustic trauma patients and healthy controls in terms of polymorphism of the A1298C and C677T methylenetetrahydrofolate receptor.

\section{DISCUSSION}

The current investigation produced three major findings. (i) Serum folate and vitamin B12 levels were decreased in patients with acoustic trauma when compared to healthy controls exposed the same acoustic overstimulation. (ii) Homocysteine levels were significantly increased in patients with acoustic trauma than in controls. (iii) Activated partial thromboplastin time was significantly shorter in patients with acoustic trauma than in healthy controls.

Acoustic trauma causes hearing loss by two main mechanisms which include mechanical and metabolic pathways. Inflammatory cytokines and free oxygen radicals are produced in the inner ear after exposure to high intensity level sound in the metabolic pathway. Inflammatory cytokines and free oxygen radicals cause a reduction in cochlear blood flow and lead to hypoxia. ${ }^{[8,9]}$ Severe acoustic overstimulation can mechanically cause loss and fusion of the inner ear sterocilia, loss of adjacent supporting cells and disruption of the organ of Corti. ${ }^{[10]}$ There can be significant differences in severity of acoustic trauma-induced hearing loss even if they occur in the same environmental conditions and at the same sound level intensity. These differences may be due to individual susceptibility to noise. ${ }^{[2]}$

Folate and vitamin B12 are both important determinants of plasma total homocysteine concentrations. Also, the low level of vitamin B12 is related with increased mean corpuscular volume. Higher homocysteine concentration (associated with low vitamin B12 status, and/or low folate status) was shown to be a risk factor for cerebral, coronary, and peripheral vascular disease. ${ }^{[11-13]}$ Hence, elevated homocysteine concentrations associated with vitamin $\mathrm{B} 12$ or folate deficiencies could lead to an adverse effect on blood flow to the cochlea. ${ }^{[14]}$ High urinary methylmalonic acid levels are associated with hiperhomocysteinemia as detected in our study. ${ }^{[11-13]}$

Folate metabolism is involved in DNA methylation and nucleotide synthesis. ${ }^{[15]}$ The enzymes represented by 5,10-methylenetetrahydrofolate reductase (MTHFR), which catalyzes the conversion of 5,10-methylenetetrahydrofolate to 5-methyltetrahydrofolate, are central to folate metabolism. MTHFR polymorphisms have attracted interest as causes of sudden sensorineural hearing loss. ${ }^{[16-19]}$ In this study, we investigated whether the MTHFR C677T and MTHFR A1298C polymorphisms are associated with acoustic trauma. However, we did not find any difference between the controls and acoustic trauma patients in terms of MTHFR polymorphisms.

Activated partial thromboplastin time was found to be below the normal values in the acoustic trauma patients. Sudden hearing loss is associated with vascular risk factors such as hyperfibrinogenemia and microembolisms. ${ }^{[20,21]} \mathrm{We}$ did not know the exact reason of shortened activated partial thromboplastin time. It might be a result of hyperhomocysteinemia, which could affect the fibrinogen and cofactor levels in the intrinsic pathway of coagulation cascade.

\section{Conclusion}

Serum homocysteine levels are elevated with folate deficiency and homocysteine is thought to be both a vascular toxin and neurotoxin. Also, poor folate status could adversely influence the vascular and nervous system of the auditory system due to the role it plays in cellular metabolism, vascular perfusion, and myelin synthesis. In addition, vitamin B12 is a nutrient thought to have similar effects on cellular mechanisms in the cochlea and its deficiency is also thought to contribute to elevated serum homocysteine levels. Hence, folate, vitamin B12 and homocysteine levels should be investigated in the acoustic trauma patients.

Another possible reason for susceptibility to hearing loss is hypercoagulopathy, and the observed changes in blood clotting may contribute, at least in part, to the pathophysiological mechanism of acoustic traumainduced hearing loss.

\section{Declaration of conflicting interests}

The authors declared no conflicts of interest with respect to the authorship and/or publication of this article. 


\section{Funding}

The authors received no financial support for the research and/or authorship of this article.

\section{REFERENCES}

1. Bapat U, Tolley N. Temporary threshold shift due to recreational firearm use. J Laryngol Otol 2007;121:927-31.

2. Quaranta A, Portalatini P, Henderson D. Temporary and permanent threshold shift: an overview. Scand Audiol Suppl 1998;48:75-86.

3. Counter SA, Klareskov B. Hypoacusis among the Polar Eskimos of northwest Greenland. Scand Audiol 1990;19:149-60.

4. Olszewski J, Miłoński J, Olszewski S, Majak J. Hearing threshold shift measured by otoacoustic emissions after shooting noise exposure in soldiers using hearing protectors. Otolaryngol Head Neck Surg 2007;136:78-81.

5. National Institute for Occupational Safety and Health USA. Criteria for a Recommended Standard: Occupational Noise Exposure-Revised Criteria DHHS (NIOSH) Publiation No.98-126. Cincinnati, Ohio: US Department of Health and Human Services, Public Health Service, Centers for Disease Control and Prevention, National Institute for Occupational Safety and Health; 1998.

6. Ylikoski ME, Ylikoski JS. Hearing loss and handicap of professional soldiers exposed to gunfire noise. Scand J Work Environ Health 1994;20:93-100.

7. Arslan HH, Satar B, Serdar MA, Ozler M, Yilmaz E. Effects of hyperbaric oxygen and dexamethasone on proinflammatory cytokines of rat cochlea in noise-induced hearing loss. Otol Neurotol 2012;33:1672-8.

8. Nuttall AL. Sound-Induced Cochlear Ischemia/Hypoxia as a Mechanism of Hearing Loss. Noise Health 1999;2:17-32.

9. Henderson D, Bielefeld EC, Harris KC, Hu BH. The role of oxidative stress in noise-induced hearing loss. Ear Hear 2006;27:1-19.

10. Cakir BO, Ercan I, Civelek S, Körpinar S, Toklu AS, Gedik O, et al. Negative effect of immediate hyperbaric oxygen therapy in acute acoustic trauma. Otol Neurotol
2006;27:478-83.

11. Eikelboom JW, Lonn E, Genest J Jr, Hankey G, Yusuf S. Homocyst(e)ine and cardiovascular disease: a critical review of the epidemiologic evidence. Ann Intern Med 1999;131:363-75.

12. Wilcken DE, Wilcken B. B vitamins and homocysteine in cardiovascular disease and aging. Ann N Y Acad Sci 1998;854:361-70.

13. Gopinath B, Flood VM, Rochtchina E, Wang JJ, Mitchell P. Homocysteine, folate, vitamin B-12, and 10-y incidence of age-related macular degeneration. Am J Clin Nutr 2013;98:129-35.

14. Gopinath B, Flood VM, Rochtchina E, McMahon CM, Mitchell P. Serum homocysteine and folate concentrations are associated with prevalent age-related hearing loss. J Nutr 2010;140:1469-74.

15. Singal R, Ferdinand L, Das PM, Reis IM, Schlesselman JJ. Polymorphisms in the methylenetetrahydrofolate reductase gene and prostate cancer risk. Int J Oncol 2004;25:1465-71.

16. Capaccio P, Ottaviani F, Cuccarini V, Ambrosetti U, Fagnani E, Bottero A, et al. Methylenetetrahydrofolate reductase gene mutations as risk factors for sudden hearing loss. Am J Otolaryngol 2005;26:383-7.

17. Uchida Y, Sugiura S, Ando F, Nakashima T, Shimokata H. Hearing impairment risk and interaction of folate metabolism related gene polymorphisms in an aging study. BMC Med Genet 2011;12:35.

18. Capaccio P, Ottaviani F, Cuccarini V, Bottero A, Schindler A, Cesana BM, et al. Genetic and acquired prothrombotic risk factors and sudden hearing loss. Laryngoscope 2007;117:547-51.

19. Huang Y, Teranishi M, Uchida Y, Nishio N, Kato K, Otake $\mathrm{H}$, et al. Association between polymorphisms in genes encoding methylenetetrahydrofolate reductase and the risk of Ménière's disease. J Neurogenet 2013;27:5-10..

20. Rudack C, Langer C, Stoll W, Rust S, Walter M. Vascular risk factors in sudden hearing loss. Thromb Haemost 2006;95:454-61.

21. Suckfüll M, Wimmer C, Reichel O, Mees K, Schorn K. Hyperfibrinogenemia as a risk factor for sudden hearing loss. Otol Neurotol 2002;23:309-11. 